\title{
Effect of diacylglycerol lipase inhibitor RHC 80267 on pancreatic mouse islet metabolism and insulin secretion
}

\author{
K. Capito, S.E.Hansen, C.J.Hedeskov and P.Thams \\ Department of Biochemistry A, The Panum Institute, University of Copenhagen, Denmark
}

\begin{abstract}
Summary. The effect of interference with diacylglycerol metabolism was investigated in pancreatic mouse islets. In the presence of the diacylglycerol lipase inhibitor RHC 80267 , glucose-induced insulin secretion was reduced $50-60 \%$; whereas carbacholin-induced insulin secretion was unaffected. Addition of the diacylglycerol kinase inhibitor R 59022 did not change glucose-stimulated insulin secretion but abolished the inhibition seen in the presence of RHC 80267. RHC 80267 increased islet glucose utilisation, measured as formation of tritiated water from $5-\left[{ }^{3} \mathrm{H}\right]$-glucose, 3-fold but did not affect glucose oxidation to $\mathrm{CO}_{2}$, lactate production or islet ATP levels. Glucose utilisation in leucocytes and hepatocytes was not increased by addition of RHC 80267. Islet lipid production from glucose was
\end{abstract}

augmented 4-fold in the presence of RHC 80267 but only accounted for about $5 \%$ of the increase in glucose utilisation. The activity of adenylate cyclase and phosphoinositide-specific phospholipase $\mathrm{C}$ was unaffected by RHC 80267 . Concentrations of RHC 80267 below $35 \mu \mathrm{mol} / 1$ did not alter the activity of phospholipase $\mathrm{A}_{2}$; whereas higher concentrations of the drug inhibited phospholipase $\mathrm{A}_{2}$ activity approx $25 \%$. The data support the hypothesis that production of arachidonic acid from diacylglycerol may be involved in regulation of insulin secretion.

Key words: Pancreatic islets, glucose metabolism, diacylglycerol, diacylglycerol lipase inhibitor.
The participation of phospholipase $\mathrm{C}$ catalysed hydrolysis of phosphatidylinositoldiphosphate $\left(\mathrm{PIP}_{2}\right)$ in regulation of insulin secretion has been substantiated during the past few years. Thus, one of the products of the reaction, inositol-1,4,5-trisphosphate has been shown to mobilise $\mathrm{Ca}^{2+}$ from an endoplasmic reticulum pool of calcium [1, 2], thereby leading to an increased conc of $\mathrm{Ca}^{2+}$ in the cytosol. The other product in the phospholipase $\mathrm{C}$ reaction, diacylglycerol, is known to stimulate protein kinase $\mathrm{C}$, which has also been suggested to be involved in regulation of insulin secretion [3-5]. Furthermore, diacylglycerol may be hydrolysed by diacylglycerol lipase and, in this way, lead to an increased production of arachidonic acid [6] which, by some authors, have been suggested to be a coupling factor in stimulus-secretion coupling in pancreatic islets $[7,8]$.

In an attempt to further elucidate the importance of diacylglycerol for regulation of insulin secretion, we have investigated the effect of the diacylglycerol lipase inhibitor, RHC 80267, [9] on insulin secretion and pancreatic islet metabolism.

Abbreviations: $\quad$ RHC $80267=(1,6-\mathrm{di}(\mathrm{O}$-(carbamoyl)cyclohexanone oxime)hexane); R $59022=6-[2-[4-[(4-f l u o r o p h e n y l)$ phenylmethyl enel-1-piperidinyl]ethyl]-7-methyl-5H-thiazolo[3,2- $\alpha$ ]pyrimidin-5-one

\section{Materials and methods}

D-[U- $\left.{ }^{14} \mathrm{C}\right]$-glucose $\quad(280 \mathrm{mCi} / \mathrm{mmol}), \quad$ D-5- $\left[{ }^{3} \mathrm{H}\right]$-glucose $\quad(10-20$ $\mathrm{Ci} / \mathrm{mmol}),{ }^{3} \mathrm{H}_{2} \mathrm{O}(5 \mathrm{mCi} / \mathrm{mmol})$ and 1-acyl-2-[14 $\left.\mathrm{C}\right]$-oleyl-glycerophosphocholine $(50 \mathrm{mCi} / \mathrm{mmol}$ ) were from Amersham Int. Buckinghamshire UK. Firefly lanterns used for preparation of luciferase was from Sigma Chemical Co, St. Louis, Mo, USA. RHC 80267 was synthesised by Dr. P.Jacobsen, Institute of Medical Chemistry, University of Copenhagen, Denmark. R 59022 was from Janssen Life Science Products, Beerse Belgium. Insulin standards, antibodies and ${ }^{125} \mathrm{I}$-insulin were given by Nordic Gentofte, Gentofte Denmark. Enzymes, including phospholipase $\mathrm{C}$ from Bacillus cereus, and coenzymes were from Boehringer, Mannheim, FRG. All other reagents were of analytical grade.

\section{Preparation of tissue}

Pancreatic islets were prepared by collagenase treatment of pancreata from male albino mice, weighing about $28 \mathrm{~g}$ each. The mice were fed ad libitum on a standard laboratory diet. Leucocytes were prepared by mixing $4 \mathrm{ml}$ of human venous blood with $1 \mathrm{ml}$ of $5 \%$ dextran solution and $10 \mu \mathrm{l}$ of heparin $(5000 \mathrm{U} / \mathrm{ml})$. The mixture was allowed to sediment for $45 \mathrm{~min}$ at $37^{\circ} \mathrm{C}$. Plasma with leucocytes and a few erythrocytes was aspirated cautiously and centrifuged for $10 \mathrm{~min}$ at low speed $(150 \times \mathrm{g})$. The pellet was resuspended and washed 3 times with Krebs-Henseleit buffer containing $16.7 \mathrm{mmol} / 1$ glucose and $1 \%$ gelatin, $0.2 \%$ sodium acetate and $1 \mathrm{mg}$ ascorbic acid $/ 100 \mathrm{ml}$. Finally, the pellet was suspended in $2 \mathrm{ml}$ of the same buffer, giving a concentration of 4-5000 leucocytes $/ \mu 1$.

Hepatocytes from rats were prepared by the collagenase method described by Dich et al. [10]. The hepatocytes were suspended in Krebs-Henseleit buffer to a concentration of 2000 cells $/ \mu 1$. 


\section{Glucose utilisation}

Glucose utilisation was measured as formation of tritiated water from $5-\left[{ }^{3} \mathrm{H}\right]$-glucose [11]. Ten islets or $6 \mu \mathrm{l}$ of hepatocyte- or leucocyte-suspension were used in each batch. RHC 80267 was dissolved in dimethylsulfoxide (DMSO). Batches without islets and islet batches with glucose plus the solvent DMSO were run as control.

\section{Glucose oxidation}

Glucose oxidation was estimated as formation of ${ }^{14} \mathrm{CO}_{2}$ from $\mathrm{U}-\left[{ }^{14} \mathrm{C}\right]-$ glucose. ${ }^{14} \mathrm{CO}_{2}$ was measured as described by Thams et al. [5]. RHC 80267 was dissolved in DMSO giving a final concentration of $0.05 \%$ DMSO in the assay.

\section{Glycogen synthesis}

Glycogen synthesis in the presence of $16.7 \mathrm{mmol} / 15-\left[{ }^{3} \mathrm{H}\right]$-glucose or $\mathrm{U}-\left[{ }^{14} \mathrm{C}\right]$-glucose was measured as described by Hedeskov \& Capito [11].

\section{Diacylglycerol lipase}

For the assay of diacylglycerol lipase 1-acyl-2-[14 C]-oleyl-glycerol was prepared from 1-oleyl-2-[ $\left.{ }^{14} \mathrm{C}\right]-$ oleyl-glycerophosphocholine: 1-oleyl$2-\left[{ }^{14} \mathrm{C}\right]$-oleyl-glycerophosphocholine was incubated for $2 \mathrm{~h}$ at $37^{\circ} \mathrm{C}$ in $200 \mu \mathrm{l}$ of $50 \mathrm{mmol} / 1$ Tris, $\mathrm{HCl} \mathrm{pH} 7.4$ containing $5 \mathrm{mmol} / 1 \mathrm{CaCl}_{2}$, $5 \mathrm{mmol} / 1 \mathrm{MgCl}_{2}$ and $2.5 \mu \mathrm{g} / \mathrm{ml}$ of phospholipase $\mathrm{C}$ from Bacillus cereus. After incubation, the lipids were extracted 4 times with $1.5 \mathrm{ml}$ of diethylether. The solvent was removed under nitrogen, and the radiolabelled lipids redissolved in petroleum ether and stored at $-20^{\circ} \mathrm{C}$. In preliminary experiments, the formed $\left[{ }^{14} \mathrm{C}\right]$-diacylglycerol was purified by thinlayer chromatography in isopropylether: acetic acid 96:4; but since the phospholipase $\mathrm{C}$ mediated hydrolysis went to completion, and the only radiolabelled product formed was 1,2-diacylglycerol, this purification was found to be unnecessary in further experiments.

The activity of diacylglycerol lipase was measured essentially as described by Rittenhouse-Simmons [12]. An aliquot of the radiolabelled diolein was evaporated under nitrogen and suspended with the help of a microprobe sonifier in $50 \mathrm{mmol} / 1$ Hepes buffer $\mathrm{pH} 7.0$ containing $100 \mathrm{mmol} / 1 \mathrm{NaCl}$ and $0.005 \%$ Triton X-100. Three five $\mu \mathrm{g}$ of islet homogenate protein was added to the suspension (final concentrations of diacylglycerol approx. $2 \mu \mathrm{mol} / \mathrm{l}$ ) in a total volume of $30 \mu \mathrm{l}$ and incubated for $30 \mathrm{~min}$ at $37^{\circ} \mathrm{C}$. RHC 80267 and indomethacin in the appropriate concns were added as DMSO solutions. The reaction was terminated by the addition of $1.5 \mathrm{ml}$ of $\mathrm{CHCl}_{3}$ : methanol: hexane $(25: 28: 20, \mathrm{v} / \mathrm{v})$. Then $0.5 \mathrm{ml}$ of $50 \mathrm{mmol} / 1$ boric acid and $50 \mathrm{mmol} / 1$ $\mathrm{K}_{2} \mathrm{CO}_{3}, \mathrm{pH} 10$ was added, and the radioactivity in the upper phase $\left({ }^{14} \mathrm{C}\right.$-oleate) was counted.

The enzyme activity was linear with time for at least $1 \mathrm{~h}$ and with the amount of islet homogenate protein untill at least $8 \mu \mathrm{g}$. Since the radioactive label was in the 2-position, the assay co-measures the activity of monoacylglycerol lipase, but since it was not possible to detect accumulation of monoacylglycerol, the two enzymes must work at least at the same rate.

\section{PI-sepcific phospholipase C}

Enzyme activity was measured in $235 \mu \mathrm{l}$ of $50 \mathrm{mmol} / 1$ Tris buffer pH 7.4 containing $1 \mathrm{mmol} / 1 \mathrm{Ca}^{2+}, 2 \mathrm{mmol} / 1 \mathrm{Li}^{+}$and $0.2 \%$ human serum albumin. The final reaction mixture included $6-7 \mu \mathrm{g}$ of sonicated islet protein and $40 \mu \mathrm{mol} / 1$ radiolabelled phosphatidylinositol added as a liposomal suspension prepared by brief sonication in $50 \mathrm{mmol} / 1$ Tris buffer $\mathrm{pH} 7.4$. The reaction was performed at $37^{\circ}$ for $15 \mathrm{~min}$ and terminated by addition of $500 \mu \mathrm{l}$ chloroform:meth- anol: concentration $\mathrm{HCl}(1: 2: 0.035, \mathrm{v} / \mathrm{v})$. After further addition of $250 \mu \mathrm{l}$ chloroform and $250 \mu \mathrm{l} 0.9 \% \mathrm{NaCl}$, phase separation was achieved by centrifugation. Released ${ }^{14} \mathrm{C}$-phosphoinositol was quantified by determination of radioactivity in the aqueous phase. The watersoluble product was identified by chromatography on Dowex-1 (formate) as being a mixture of inositol-1-monophosphate and 1,2-cyclic inositolmonophosphate. Measured under these conditions, the activity of PI-specific phospholipase $\mathrm{C}$ in fresh islet homogenate was $1.76 \pm 0.22 \mathrm{pmol} \cdot \mathrm{min} \cdot \mathrm{islet}(n=12)$. The aqueous phase did not contain ${ }^{14} \mathrm{C}$-inositol. The enzyme also hydrolyses phosphatidylinositol 4,5-diphosphate.

\section{Other enzyme assays}

Adenylate cyclase was measured as described by Thams et al. [13]. Phospholipase $\mathrm{A}_{2}$ activity was measured as formation of $\left[{ }^{14} \mathrm{C}\right]$-oleate from 1-oleyl-2-[14 C]-oleyl-glycerophosphocholine. The substrate was suspended in Hepes-buffer $(50 \mathrm{mmol} / 1 ; \mathrm{pH} 7.0)$, containing $2 \mathrm{mmol} / 1 \mathrm{CaCl}_{2}$ and incubated with islet homogenate for $2 \mathrm{~h}$ at $37^{\circ} \mathrm{C}$. The reaction was stopped, and the liberated oleic acid measured as described above for the diacylglycerol lipase assay.

\section{ATP-determination}

For measurement of ATP, batches of 15 islets were incubated for $45 \mathrm{~min}$ at $37^{\circ} \mathrm{C}$ in $40 \mu \mathrm{l}$ of Krebs buffer containing $16.7 \mathrm{mmol} / 1 \mathrm{glu}-$ cose and $70 \mu \mathrm{mol} / 1 \mathrm{RHC} 80267$ or $0.1 \%$ DMSO. The incubation was terminated by addition of $20 \mu 1$ of ice-cold $1 \mathrm{~mol} / 1$ perchloric acid, and ATP determined by the luciferase method described in [11], except that $250 \mu \mathrm{l}$ of $0.2 \mathrm{~mol} / \mathrm{1}$ Tris, acetate buffer $\mathrm{pH} 7.75$, containing $2 \mathrm{mmol} / 1 \mathrm{MgSO}_{4}$ and $1 \mathrm{mmol} / 1$ EDTA was used as assay buffer.

\section{Lactate production}

Twenty islets were incubated for $2 \mathrm{~h}$ at $37^{\circ} \mathrm{C}$ in $50 \mu \mathrm{l}$ of Krebs buffer containing glucose $(3.3$ or $16.7 \mathrm{mmol} / \mathrm{l})$. Metabolism was arrested by addition of $70 \mu \mathrm{l}$ of $50 \mathrm{mmol} / 1 \mathrm{HCl}$. The tubes were heated at $60^{\circ} \mathrm{C}$ for $30 \mathrm{~min}$ to destroy endogenous NADH. After cooling and centrifugation, $2 \times 50 \mu 1$ of the supernatant were transferred to cuvettes containing $1.2 \mathrm{ml}$ of $0.4 \mathrm{~mol} / \mathrm{l}$ glycin buffer $\mathrm{pH} 9.5$ with $0.16 \mathrm{~mol} / 1$ hydrazin, $2 \mathrm{mmol} / 1$ EDTA, $0.01 \mathrm{mmol} / 1 \mathrm{NAD}^{+}$and $3.6 \mathrm{U}$ of lactate dehydrogenase. After incubation at room temperature for $30 \mathrm{~min}$, the fluorescence of the formed NADH was measured at a Ferrand fluorimeter. Blanks and standards were taken through the whole procedure.

\section{Lipid synthesis}

Sixty islets were incubated at $37^{\circ} \mathrm{C}$ for $2 \mathrm{~h}$ in $60 \mu \mathrm{l}$ of Krebs buffer containing $16.7 \mathrm{mmol} / 1 \mathrm{U}-{ }^{14} \mathrm{C}$-glucose (spec. activity $3 \mathrm{mCi} / \mathrm{mmol}$ ). After incubation, the medium was removed and the islets were washed once with Krebs buffer. $100 \mu \mathrm{l}$ of $1 \mathrm{~mol} / \mathrm{l}$ citrate buffer, $\mathrm{pH} 3.0$ and $1.8 \mathrm{ml}$ of $\mathrm{CHCl}_{3}$ :methanol $(1: 2)$ were added and the tubes were shaken for $30 \mathrm{~min}$. Then, $1.5 \mathrm{ml}$ of $\mathrm{CHCl}_{3}$ and $1.5 \mathrm{ml}$ of $2 \mathrm{~mol} / 1 \mathrm{KCl}$ were added followed by another $30 \mathrm{~min}$ of extraction of lipids. After extraction, the radioactivity in the chloroform phase was measured.

\section{Determination of radiolabelled glycerol and anionic metabolites}

Batches of 15 islets were incubated in $20 \mu \mathrm{l}$ of Krebs buffer containing $0.83 \mu \mathrm{Ci}$ of $\mathrm{U}-\left[{ }^{14} \mathrm{C}\right]$-glucose at a concentration of 3.3 or $16.7 \mathrm{mmol} / 1$ glucose and in the absence or presence of $70 \mu \mathrm{mol} / 1 \mathrm{RHC} 80267$ or $0.05 \%$ DMSO. Parallel controls were run without islets. The incuba- 
tion was carried out for $2 \mathrm{~h}$ at $37^{\circ} \mathrm{C}$ and stopped by the addition of $10 \mu 1$ of $4 \%$ Triton X-100. After $10 \mathrm{~min}$ at room temperature, the samples were immersed briefly in a boiling water bath and cooled on ice. Glycerol in the samples was phosphorylated by adding $20 \mu l$ of $0.3 \mathrm{~mol} / 1$ Tris-buffer $\mathrm{pH} 7.5$, containing $5 \mathrm{mmol} / 1 \mathrm{ATP}, 0.1 \mathrm{~mol} / 1$ $\mathrm{MgSO}_{4}$ and $4.3 \mathrm{U} / \mathrm{ml}$ of glycerokinase and incubating for $30 \mathrm{~min}$ at $37^{\circ} \mathrm{C}$. After completion of the phosphorylation reaction, aliquots of $40 \mu 1$ were spotted on Whatman DE 81 anion exchange paper. The disks were dried and cautiously rinsed with a slow stream of water for about $10 \mathrm{~min}$. After drying, the disks were transferred to $10 \mathrm{ml}$ of instagel II, thus measuring the radioactivity in glycerol and anionic metabolites.

\section{Insulin secretion}

Insulin secretion experiments were done as batch type incubations [14] and the secreted insulin measured in a radioimmunoassay.

\section{Statistical analysis}

Statistical evaluation of the data was made by use of Students t-test.

\section{Results}

\section{Diacylglycerol lipase activity}

The activity of diacylglycerol lipase in a homogenate of pancreatic islets was found to be $89 \pm 10 \mathrm{pmol} \cdot \mathrm{min} \cdot \mathrm{mg}$ protein $^{-1}$ (mean \pm SEM; $n=3$ ). RHC 80267 at a conc of $35 \mu \mathrm{mol} / 1$ inhibited the enzyme activity $90 \pm 2 \%$ (mean $\pm \mathrm{SEM}, n=4$ ). From dose-response studies $(n=4)$, it was calculated that a $50 \%$ inhibition of the enzyme activity was obtained at $6 \mu \mathrm{mol} / \mathrm{I}$ RHC 80267. This is similar to the effects described by Sutherland and Amin in canine platelets [9]. Indomethacin at a concentration of $140 \mu \mathrm{mol} / 1$, which in some tissues inhibits diacylglycerol lipase [12], did not affect the activity of diacylglycerol lipase in islets. $\mathrm{Ca}^{2+}$, which in some tissues activate diacylglycerol lipase [15], did not affect the islet enzyme activity in a concentration of $1 \mathrm{mmol} / \mathrm{l}$.

\section{Insulin secretion}

Dose-response studies of the effect of $17.5-70 \mu \mathrm{mol} / 1$ RHC 80267 on insulin secretion was measured at 3 different glucose concentrations and in the presence of $5 \mathrm{mmol} / 1$ glucose plus $100 \mu \mathrm{mol} / 1$ carbacholine (Table 1).

Thirty-five $\mu \mathrm{mol} / 1$ RHC 80267 inhibited insulin secretion induced by 10 or $17 \mathrm{mmol} / 1$ glucose $45 \%$, and addition of $70 \mu \mathrm{mol} / 1$ RHC 80267 at these glucose concentrations reduced the insulin secretory rate to basal values. The basal secretory rate was unaffected by addition of RHC 80267 (results not shown). Insulin secretion potentiated by carbacholine was also unaffected by addition of RHC 80267.
Table 1. Insulin secretion was measured in batch type incubations for $2 \mathrm{~h}$. RHC 80267 was dissolved in dimethylsulfoxide (DMSO) and added in final concentration of $17.5,35$ and $70 \mu \mathrm{mol} / 1 \mathrm{RHC} 80267$ and $0.1 \%$ DMSO. DMSO alone did not affect the insulin secretion. In another series of experiments, carbacholin was added in the presence of $5 \mathrm{mmol} / 1$ glucose. The results are given as $\mu \mathrm{U}$ insulin. 5 islets $\cdot 2 \mathrm{~h} \pm$ SEM with the number of batches in parentheses

\begin{tabular}{lc}
\hline Addition & Insulin secretion \\
\hline $3 \mathrm{mmol} / 1$ glucose & $601 \pm 97(23)$ \\
$10 \mathrm{mmol} / 1$ glucose & $1177 \pm 123(23)$ \\
$10 \mathrm{mmol} / 1$ glucose $+17.5 \mu \mathrm{mol} / 1 \mathrm{RHC}$ & $1094 \pm 224(22)$ \\
$10 \mathrm{mmol} / 1$ glucose $+35 \mu \mathrm{mol} / 1 \mathrm{RHC}$ & $909 \pm 101(22)$ \\
$10 \mathrm{mmol} / 1$ glucose $+70 \mu \mathrm{mol} / 1 \mathrm{RHC}$ & $654 \pm 76(22)^{\mathrm{a}}$ \\
$17 \mathrm{mmol} / 1$ glucose & $2205 \pm 445(20)$ \\
$17 \mathrm{mmol} / 1$ glucose $+17.5 \mu \mathrm{mol} / 1 \mathrm{RHC}$ & $1937 \pm 586(20)$ \\
$17 \mathrm{mmol} / 1$ glucose $+35 \mu \mathrm{mol} / 1 \mathrm{RHC}$ & $1154 \pm 229(20)^{\mathrm{a}}$ \\
$17 \mathrm{mmol} / 1$ glucose $+70 \mu \mathrm{mol} / 1 \mathrm{RHC}$ & $697 \pm 117(20)^{\mathrm{a}}$ \\
$5 \mathrm{mmol} / 1$ glucose & $580 \pm 80(12)$ \\
$100 \mu \mathrm{mol} / 1$ carbachol & $878 \pm 60(15)$ \\
$100 \mu \mathrm{mol} / 1$ carbachol $+70 \mu \mathrm{mol} / 1 \mathrm{RHC}$ & $822 \pm 92(14)$ \\
\hline
\end{tabular}

${ }^{\mathrm{a}} p<0.05$ vs control without RHC 80267

Table 2. Insulin secretion was measured in batch type incubations as described in the text to Table 1 . R 59022 was added as a DMSO solution in a final concentration of $50 \mu \mathrm{mol} / 1 \mathrm{R} 59022$ and $0.1 \%$ DMSO

\begin{tabular}{lr}
\hline Addition & $\mu U \cdot 5$ islets $\cdot 2 \mathrm{~h}$ \\
\hline $3.3 \mathrm{mmol} / \mathrm{l}$ glucose & $366 \pm 100(15)$ \\
-+ R 59022 & $400 \pm 99(14)$ \\
-+ R 59022+RHC $80267(70 \mu \mathrm{mol} / \mathrm{l})$ & $497 \pm 105(15)$ \\
10 mmol/1 glucose & $895 \pm 59(37)$ \\
-+ R 59022 & $1041 \pm 93(36)$ \\
-+ R 59022+RHC $80267(70 \mu \mathrm{mol} / \mathrm{l})$ & $987 \pm 138(37)$ \\
\hline
\end{tabular}

In another series of experiments, the effect of a combined addition of RHC 80267 and the diacylglycerol kinase inhibitor R 59022 was investigated (Table 2). In this case, no significant effect of either R 59022 or R 59022 plus RHC 80267 could be demonstrated.

\section{Glucose utilisation}

Glucose utilisation was measured as formation of tritiated water from $5-\left[{ }^{3} \mathrm{H}\right]$-glucose during a $2 \mathrm{~h}$ incubation of pancreatic islets. In the presence of $16.7 \mathrm{mmol} / 1$ glucose RHC 80267 stimulated the glucose utilisation in a dose-dependent manner, reaching a 5 -fold stimulation relative to the DMSO-control at $140 \mu \mathrm{mol} / 1 \mathrm{RHC} 80267$ (Table 3). At 3 and $10 \mathrm{mmol} / 1$ glucose a similar activation was seen (results not shown).

It is noteworthy that DMSO, which is used as a solvent for RHC 80267 , exhibits in itself an inhibitory effect on glucose utilisation. At a DMSO-concentration of $0.5 \%$ the inhibition was about 50\% (not shown). This is remarkable as DMSO is usually considered relatively harmless and biologically indifferent. The inhibitory effect of DMSO was not seen in experiments with hepatocytes and leucocytes. 
Table 3. Glucose utilisation at $16.7 \mathrm{mmol} / 1$ glucose was measured as formation of tritiated water from $5-\left[{ }^{3} \mathrm{H}\right]$-glucose. Results are expressed as pmol glucose utilised $2 \mathrm{~h} \cdot$ islet with the number of experiments in parentheses

\begin{tabular}{llr}
\hline $\begin{array}{l}\text { Concentration of } \\
\text { RHC 80267 } \\
\mu \mathrm{mol} / 1\end{array}$ & $\begin{array}{l}\text { Concentration of } \\
\text { DMSO } \\
\%\end{array}$ & $\begin{array}{l}\text { Glucose utilisation } \\
\text { pmol } \cdot 2 \mathrm{~h} \cdot \text { islet }\end{array}$ \\
\hline 0.00 & 0.00 & $42.4 \pm 6.5(5)$ \\
0.00 & 0.04 & $29.3 \pm 3.1(6)$ \\
8.75 & 0.04 & $53.3 \pm 6.2(3)$ \\
17.50 & 0.04 & $78.3 \pm 16.5(3)$ \\
35.00 & 0.04 & $92.9 \pm 9.3(6)$ \\
70.00 & 0.04 & $126.8 \pm 6.9(3)$ \\
140.00 & 0.04 & $165.0 \pm 8.7(3)$ \\
\hline
\end{tabular}

Table 4. Glucose oxidation from $\mathrm{U}-\left[{ }^{14} \mathrm{C}\right]$-glucose and lactate production was measured in pancreatic islets as described in the Experimental Section. Incubation was carried out for $2 \mathrm{~h}$ at $37^{\circ} \mathrm{C}$. Results are given as pmol glucose oxidised to $\mathrm{CO}_{2}$ or pmol lactate produced per $2 \mathrm{~h}$ per islet (mean $\pm S E M$ ), with the number of batches of islets in parentheses

\begin{tabular}{lcc}
\hline Addition & Glucose oxidation & Lactate production \\
\cline { 2 - 3 } & $\mathrm{pmol} \cdot$ islet $\cdot 2 \mathrm{~h}$ & \\
\hline $3.3 \mathrm{mmol} / 1$ glucose & $4.8 \pm 0.9(14)$ & $15.7 \pm 2.8(41)$ \\
$16.7 \mathrm{mmol} / 1$ glucose & $23.2 \pm 3.5(15)$ & $35.0 \pm 8.5(49)$ \\
$16.7 \mathrm{mmol} / 1$ glucose + & & \\
$35 \mu \mathrm{mol} / 1 \mathrm{RHC} 80267$ & $24.3 \pm 5.5(15)$ & $30.1 \pm 5.8(49)$ \\
$16.7 \mathrm{mmol} / 1$ glucose + & & \\
$0.01 \% \mathrm{DMSO}$ & $21.3 \pm 4.1(15)$ & $36.0 \pm 15.1 \quad(8)$ \\
\hline
\end{tabular}

The stimulating effect of RHC 80267 is probably rather specific for pancreatic islets, since in 3 experiments with hepatocytes (glucose concentration = $16.7 \mathrm{mmol} / 1$, conc of $\mathrm{RHC} 80267=70 \mu \mathrm{mol} / \mathrm{l}$, and DMSO concentration $=0.02 \%)$ the glucose utilisation was $82 \pm 9 \%$ (mean \pm SEM) of control values. Under the same conditions, the stimulation of islet glucose utilisation was $286 \pm 24 \%$ of the control. In 4 experiments with leucocytes under the same assay conditions, glucose utilisation was $76 \pm 2 \%$ of the control.

As an uncoupling effect of RHC 80267 on the oxidative phosphorylation in the islets might explain the increased glucose utilisation, a few experiments with $50 \mu \mathrm{mol} / 1$ dinitrophenol in the presence of $16.7 \mathrm{mmol} / 1$ glucose were performed in pancreatic islets. No significant stimulation of glucose utilisation was observed (results not shown). Measurements of islet ATP-content after incubation with $16.7 \mathrm{mmol} / 1$ glucose \pm RHC 80267 also indicated that RHC 80267 does not act as an uncloupling agent. Thus, the ATP content amounted to $4.9 \pm 0.7 \mathrm{pmol} /$ islet in the absence and $5.6 \pm 0.8$ $\mathrm{pmol} /$ islet in the presence of RHC 80267 (mean \pm SEM, $n=9$ ). The DMSO solvent did not affect the islet ATP content significantly.

Indomethacin $(47 \mu \mathrm{mol} / 1)$ in the presence of $10 \mathrm{mmol} / 1$ glucose and $0.02 \%$ DMSO in 2 experiments increased glucose utilisation to 174 and $159 \%$ of the control, respectively. In the presence of $16.7 \mathrm{mmol} / 1$ glucose the values obtained were 278 and $225 \%$, respectively.

\section{Glucose oxidation and lactate production}

During metabolism of $5-\left[{ }^{3} \mathrm{H}\right]$-glucose, tritiated water is formed in the pentose cycle, in the triosephosphate isomerase reaction and in the enolase reaction, thus giving a measurement of glucose metabolism via glycolysis plus pentose cycle, as well as glycerolipid formation from glucose. In pancreatic islets, pentose cycle activity contributes approximately $3 \%$ [16] and glycerolipid production $3-6 \%$ [17] to the total glucose utilisation measured during incubation with $16.7 \mathrm{mmol} / 1$ glucose. To evaluate the effect of RHC 80267 on total glucose oxidation and on glycolysis, the possible effect of the diacylglycerol lipase inhibitor on ${ }^{14} \mathrm{CO}_{2}$-production from $\mathrm{U}-\left[{ }^{14} \mathrm{C}\right]$-glucose and lactate production was investigated (Table 4).

As expected, glucose $(16.7 \mathrm{mmol} / 1)$ significantly ( $p<0.001$ and 0.05 respectively) accelerated the glucose oxidation and lactate production. Surprisingly, addition of RHC 80267 or the solvent alone did not affect these parameters.

\section{Conversion of glucose to glycerol, anionic metabolites and lipids}

The possible effect of RHC 80267 on metabolism of glucose through the lipogenetic pathway was estimated by measuring the production of radioactive lipids and radioactive anionic metabolites + glycerol formed during incubation with $16.7 \mathrm{mmol} / 1 \mathrm{U}-\left[{ }^{14} \mathrm{C}\right]$-glucose in the absence or presence of RHC 80267.

Addition of RHC $80267(35 \mu \mathrm{mol} / \mathrm{l})$ to the assay medium increased the production of radioactive lipids 4-fold, leading to a conversion of $2.9 \pm 1.9$ pmol glucose $\cdot$ islet $\cdot 2 \mathrm{~h}$ (mean $\pm \mathrm{SEM}, n=5$ ) to lipids. However, this increase in lipid production only accounts for about $5 \%$ of the increase in glucose utilisation seen in the presence of RHC 80267.

During $2 \mathrm{~h}$ of incubation with $16.7 \mathrm{mmol} / 1$ glucose, $6.5 \pm 1.1 \mathrm{pmol}$ glucose/islet (mean $\pm \operatorname{SEM}, n=4$ ) was converted to anionic intermediates + glycerol. This is 5fold higher than seen in the presence of $3.3 \mathrm{mmol} / 1 \mathrm{glu}-$ cose. Addition of $35 \mu \mathrm{mol} / \mathrm{I}$ RHC 80267 at high glucose concentration decreased the radioactivity found in anionic intermediates + glycerol slightly, corresponding to a conversion of $5.1 \pm 1.2 \mathrm{pmol}$ glucose/islet (mean \pm SEM, $n=4)$. Due to the small differences, an attempt to separate the different radioactive anions was not made.

\section{Glycogen synthesis}

It is not known whether glycogen synthesis from glucose in islets proceeds via glucose 6-phosphate and glucose 1-phosphate directly or via an indirect pathway in- 
volving triosephosphates as may be the case in the liver [18]. If the latter is true, different radioactivity incorporation into glycogen would be expected when glycogen synthesis is measured with ${ }^{3} \mathrm{H}$-glucose and ${ }^{14} \mathrm{C}$-glucose as substrate.

In the indirect pathway, a possible RHC 80267 stimulation of glycogen synthesis would be reflected in an increase in formation of tritiated water and might thus theoretically explain at least part of the difference demonstrated above concerning RHC 80267 effects on $5-\left[{ }^{3} \mathrm{H}\right]$-glucose utilisation and enzymatically measured lactate production. One would expect to observe a lower relative incorporation of $5-\left[{ }^{3} \mathrm{H}\right]$-glucose than of $\mathrm{U}-\left[{ }^{14} \mathrm{C}\right]$-glucose into glycogen, since $5-\left[{ }^{3} \mathrm{H}\right]$-glucose in this pathway would lose its tritium label to water. RHC 80267 would further enhance this effect. However, glycogen synthesis measured in the presence of $5-\left[{ }^{3} \mathrm{H}\right]$-glucose or $\mathrm{U}-\left[{ }^{14} \mathrm{C}\right]$-glucose was identical $(2.18 \pm 0.39 \mathrm{pmol}$ glycosyl units/islet $(n=4)$ and $2.24 \pm 0.44 \mathrm{pmol}$ glycosyl units/islet $(n=4)$, respectively) and was, furthermore, not affected by the addition of RHC 267.

\section{RHC 80267 effects on other islet parameters}

It was not possible to detect any effect of 35-70 $\mu \mathrm{mol} / 1$ RHC 80267 on the activity of adenylate cyclase or phosphoinositide specific phospholipase $C$, when these enzymes were measured in an islet homogenate. $17.5-35 \mu \mathrm{mol} / 1 \mathrm{RHC} 80267 \mathrm{did}$ not affect the activity of phospholipase $\mathrm{A}_{2}$; whereas higher concentrations of the drug inhibited the activity of phospholipase $A_{2}$ approx. $25 \%$.

\section{Discussion}

RHC 80267 was originally described by Sutherland and Amin [9] as a potent inhibitor of diacylglycerol lipase in enzyme-rich supernatants prepared from canine platelets. Since then this inhibitory effect of the drug has been confirmed in other tissues $[19,20]$ although some authors have been unable to demonstrate any effects [21, 22]. The drug is described as being able to enter cells [9] and thus seems an appropriate tool to study the effects of interference with intracellular diacylglycerol metabolism on secretion. RHC 80267 seems to be relatively non-toxic, since the viability of rat pituitary tumor cells has been shown to be unaffected over $4 \mathrm{~h}$ of incubation [23]. In concentrations less than approximately $100 \mu \mathrm{mol} / 1$, the drug seems to be rather specific; whereas higher concentrations affect several enzymes involved in leukotrien- and prostacyclin synthesis (unpublished observations).

In concentrations from $10-100 \mu \mathrm{mol} / 1$, the drug has been shown to inhibit prolactin release [23], to inhibit thyrotropin-stimulated prostaglandin release from rat thyroid lobes [19] and to inhibit carbacholine-induced amylase secretion from guinea pig pancreatic minilobules [24]. In the present experiments with mouse pancreatic islets, $35 \mu \mathrm{mol} / 1 \mathrm{RHC} 80267$ was shown to inhibit glucose-induced insulin secretion $45 \%$; whereas no effect could be demonstrated on carbachol-induced insulin secretion.

As demonstrated in other tissues [20], inhibition of diacylglycerol lipase supposedly results in an increased concentration of diacylglycerol and a reduced formation of monoacylglycerol and fatty acids, especially interesting arachidonic acid. Increased concentration of diacylglycerol would be expected to stimulate insulin secretion due to activation of protein kinase C [3-5]. Reduced formation of arachidonic acid might lead to an inhibition of insulin release as was actually found in the present experiments, since arachidonic acid, either in itself or through metabolism via the lipoxygenase pathway, is supposed to potentiate insulin secretion [7,8].

The finding that $70 \mu \mathrm{mol} / 1$ RHC 80267 inhibits both diacylglycerol lipase and glucose-induced insulin secretion almost $100 \%$ suggest that arachidonic acid production from diacylglycerol is normally involved in insulin secretion. In comparison, the observation that RHC 80267 does not inhibit carbachol-enhanced secretion is intriguing. It must, however, be taken into consideration that arachidonic acid may also be liberated by a phospholipase $\mathrm{A}_{2}$ reaction, and that phospholipase $\mathrm{A}_{2}$ may be activated by an increase in diacylglycerol $[25,26]$. The relative importance of proteinkinase $C$, phospholipase $\mathrm{A}_{2}$ and diacylglycerol lipase in glucoseinduced and carbachol-induced insulin secretion is not known, but diacylglycerol activation of protein kinase $\mathrm{C}$ and phospholipase $\mathrm{A}_{2}$ may counteract the possible inhibition by RHC 80267 of carbachol-induced secretion. Specific inhibitors of these two enzymes in islets have so far not been demonstrated, but it is possible that a selective inhibition of these enzymes would unmask a more major inhibitory effect of RHC 80267 on carbachol-induced secretion.

It is interesting that a 3-4 fold increase in glucose utilisation, measured as formation of tritiated water from $5-\left[{ }^{3} \mathrm{H}\right]$-glucose, which to our knowledge always has been found to be positively correlated with insulin secretion, is not able to counteract the effect of a reduced production of arachidonic acid on insulin secretion.

The reason for the increase in glucose utilisation in the presence of RHC 80267 is not obvious. Our finding that also the cyclooxygenase inhibitor indomethacin increases glucose utilisation and the observation that prostaglandin $\mathrm{E}_{2}$ inhibits glucose-stimulated insulin secretion [27] may indicate the existence of a feed-back regulatory mechanism between arachidonic acid metabolism and glucose utilisation, which, furthermore, may be specific for secretory tissues, as the effect of RHC 80267 on glucose utilisation is not seen in non-secretory tissues as leucocytes and hepatocytes. 
A considerable stimulatory effect of cGMP on glucose utilisation has previously been shown in pancreatic rat islets [28], and in the presence of IBMX, the ester phorbol 12,13-dibutyrate has been shown to reverse the inhibitory action of the $\alpha_{2}$-adrenoceptor agonist clonidine upon islet glucose utilisation [29]. The latter effect was ascribed to a protein kinase $\mathrm{C}$ mediated activation of guanylate cyclase, but other protein kinase $\mathrm{C}$ mediated effects on glucose utilisation cannot be excluded.

In guinea pig pancreatic minilobules, RHC 80267 has been shown to inhibit production of cyclic GMP [24], and it thus seems rather unlikely that the increase in glucose utilisation observed in the present experiment is due to cyclic GMP. However, since the concentration of diacylglycerol is assumed to be elevated in the presence of RHC 80267, other protein kinase C mediated effects on glucose utilisation cannot be excluded in this study either. It should, however, be stressed that phorbolesters do not activate glucose utilisation in the uninhibited basal state $[4,29]$.

Unfortunately, our results are obscured by the unexpected finding that glucose utilisation measured as formation of tritiated water from $5-\left[{ }^{3} \mathrm{H}\right]$-glucose in the presence of RHC 80267 is not correlated with either production of ${ }^{14} \mathrm{CO}_{2}$ from $\mathrm{U}-\left[{ }^{14} \mathrm{C}\right]-$ glucose or lactate production. It thus seems, that RHC 80267 may interfere with glucose metabolism at more than one stage, at the same time accelerating the pre-pyruvate part of metabolism and not affecting the mitochondrial metabolic events. The latter finding may signal an unchanged ATP-demand in the cells. It is interesting that a similar disproportionate effect on glucose utilisation and glucose oxidation is seen both in parotid cells and in RINm5F cells upon raising the glucose concentration $[30,31]$.

In an attempt to determine which pathway is responsible for the increased production of tritiated water, we have investigated the effect of RHC 80267 on formation of lipids, glycerol and anionic intermediates derived from glucose. We have also looked for RHC-effects on glycogen synthesis, as this pathway might be co-measured during certain conditions. However, although RHC 80267 does increase lipid formation from glucose 4-fold, this effect is far too small to explain the observed effect of RHC 80267 on glucose utilisation. The mechanism of the latter effect thus remains to be determined.

Although a reduced production of arachidonic acid seems to be the most obvious explanation for the observed inhibition of insulin secretion, other explanations are possible. Thus in pituitary tumor cells, RHC 80267 has been found to inhibit ${ }^{45}$ calcium entry through the voltage-dependent calcium channels [23], and diacylglycerol-stimulated protein kinase $\mathrm{C}$ has been shown to activate $\mathrm{IP}_{3}$ phosphomonoesterase [32]. A similar effect in pancreatic islets would be expected to result in inhibition of glucose-induced insulin secretion [33].
One of the aims of the present study was to evaluate if potentiation of insulin secretion is regulated by an increase in the intracellular concentration of diacylglycerol. In doing this, we have attempted to raise the concentration of diacylglycerol by addition of RHC 80267 . As discussed above, it seems, however, that a possible positive effect of diacylglycerol is obscured by other effects of the diacylglycerol lipase inhibitor.

Demonstration of a diacylglycerol activation of insulin secretion might also be complicated by the transient nature of the increase in diacylglycerol, which has been demonstrated in islets [34] as well as in other tissues [35] and which may even persist in the presence of RHC 80267 due to a rapid conversion of diacylglycerol to phosphatidic acid.

To overcome this problem, we have also measured insulin secretion in the presence of R 59022 , which has been shown to inhibit diacylglycerol kinase in human red blood cells [36]. Addition of this agent in combination with RHC 80267 resulted in a complete reversal of the inhibition seen in the presence of RHC 80267 alone and may thus indicate that an increase in endogenous diacylglycerol does stimulate insulin secretion, although it remains to be determined if the increase in the concentration of diacylglycerol established by secretagogues in the absence of inhibitors of diacylglycerol metabolism is sufficient to activate protein kinase $\mathrm{C}$ in the islets.

In conclusion, our results support the suggestion [6] that arachidonic acid production from diacylglycerol is normally involved in the regulation of insulin secretion, and they indicate that endogenously produced diacylglycerol may indeed affect insulin secretion. The results, furthermore, have shown that increased glucose utilisation, as measured by formation of tritiated water from $5-\left[{ }^{3} \mathrm{H}\right]-$ glucose, is not necessarily associated with enhanced insulin secretion.

Acknowledgements. The study was supported by financial aid from The Danish Diabetes Association, P.Carl Petersen Foundation, The Nordic Insulin Foundation and Dr. med. E. Garde and wife Elisabeth Gardes Foundation. The technical assistance of Mrs. A. Sommerfeldt and Mrs. B.Vinther is gratefully acknowledged. We thank Dr. P. Jacobsen for synthesising the RHC 80267 and Dr. J.Dich for assistance in preparation of the hepatocytes.

\section{References}

1. Berridge MJ (1984) Inositol trisphosphate and diacylglycerol as second messengers. Biochem J 220:345-360

2. Biden TJ, Prentki M, Irvine RF, Berridge MJ, Wollheim CB (1984) Inositol 1,4,5-trisphosphate mobilizes intracellular $\mathrm{Ca}^{2+}$ from permeabilized insulin-secreting cells. Biochem J 223: 467-473

3. Virji MAG, Steffes MW, Estensen RD (1978) Phorbol myristate acetate: Effect of a tumor promoter on insulin release from isolated rat islets of Langerhans. Endocrinology 102: 706-711

4. Malaisse WJ, Sener A, Herchuelz A, Carpinelli AR, Poloczek $P$, Winand J, Castagna M (1980) Insulinotropic effect of the tumor promoter 12-O-tetradecanoylphorbol-13-acetate in rat pancreatic islets. Cancer Res 40: 3827-3831 
5. Thams P, Capito K, Hedeskov CJ (1986) An inhibitory role for polyamines in protein kinase $\mathrm{C}$ activation and insulin secretion in mouse pancreatic islets. Biochem J 237: 131-138

6. Schrey MP, Montague W (1983) Phosphatidylinositol hydrolysis in isolated guinea-pig islets of Langerhans. Biochem J 216: 433-441

7. Turk J, Colca JR, McDaniel ML (1985) Arachidonic acid metabolism in isolated pancreatic islets. III. Effects of exogenous lipoxygenase products and inhibitors on insulin secretion. Biochim Biophys Acta 834: 25-36

8. Metz SA (1986) Putative roles for lysophospholipids as mediators and lipoxygenase-mediated metabolites of arachidonic acid as potentiators of stimulus-secretion coupling: dual mechanisms of p-hydroxymercuribenzoic acid-induced insulin release. J Pharmacol Exp Ther 238: 819-832

9. Sutherland CA, Amin D (1982) Relative activities of rat and dog platelet phospholipase $\mathrm{A}_{2}$ and diglyceride lipase. J Biol Chem 257: $14006-14010$

10. Dich J, Bro B, Grunnet N, Jensen F, Kondrup J (1983) Accumulation of triacylglycerol in cultured rat hepatocytes is increased by ethanol and by insulin and dexamethasone. Biochem $J 212$ : $617-623$

11. Hedeskov CJ, Capito K (1974) The effect of starvation on insulin secretion and glucose metabolism in mouse pancreatic islets. Biochem J 140: 423-433

12. Rittenhouse-Simmons S (1980) Indomethacin-induced accumulation of diglyceride in activated human platelets. J Biol Chem 255: $2259-2262$

13. Thams P, Capito K, Hedeskov CJ (1984) Characteristics of an adenylate cyclase enhancing factor from mouse pancreatic islet cytosol. Diabetologia 26:375-378

14. Hedeskov CJ, Capito K (1975) The restoring effect of caffeine on the decreased sensitivity of the insulin secretory mechanism in mouse pancreatic islets during starvation. Horm Metab Res 7:1-5

15. Mauco G, Fauvel J, Chap H, Douste-Blazy L (1984) Studies on enzymes related to diacylglycerol production in activated platelets. Biochim Biophys Acta 796: 169-177

16. Hedeskov CJ, Capito K (1975) The pentose cycle and insulin release in isolated mouse pancreatic islets during starvation. Biochem J 152: 571-576

17. Berne C (1974) Studies on the lipid metabolism in the pancreatic B-cells of mice. Acta Universitatis Upsaliensis No 215

18. McGarry JD, Kuwajima M, Newgard CB, Foster DW, Katz J (1987) From dietary glucose to liver glycogen: the full circle round. Ann Rev Nutr 7: 51-73

19. Levasseur S, Kostelec M, Burke G (1984) RHC 80267 inhibits thyrotropin-stimulated prostaglandin release from rat thyroid lobes. Prostaglandins 27: 673-682

20. Dixon JF, Hokin LE (1984) Secretagogue-stimulated phosphatidylinositol breakdown in the exocrine pancreas liberates arachidonic acid, stearic acid, and glycerol by sequential actions of phospholipase $\mathrm{C}$ and diglyceride lipase. J Biol Chem 259: 14418-14425

21. Oglesby TD, Gorman RR (1984) The inhibition of arachidonic acid metabolism in human platelets by RHC 80267, a diacylglycerol lipase inhibitor. Biochem Biophys Acta 793: 269-277

22. Bross TE, Prescott SM, Majerus PW (1983) RHC 80267 does not inhibit the diglyceride lipase pathway in intact platelets. Biochem Biophys Res Commun 116: 68-74

23. Camoratto AM, Grandison L (1987) Effects of RHC 80267, a diglyceride lipase inhibitor, on prolactin secretion and calcium uptake in $\mathrm{GH}_{3}$ pituitary cells. Life Sci 40: 275-281

24. Sekar MC, Hokin LE (1987) Inhibitors of diacylglycerol lipase and diacylglycerol kinase inhibit carbamylcholine-stimulated responses in guinea pig pancreatic minilobules. Arch Biochem Biophys 256: 509-514

25. Volpi M, Molski TFP, Naccache PH, Feinstein MB, Sha'afi RI (1985) Phorbol 12-myristate 13 acetate potentiates the action of the calcium ionophore in stimulating arachidonic acid release and production of phosphatidic acid in rabbit neutrophils. Biochem Biophys Res Commun 128: 594-600

26. Matsumoto T, Tao W, Shaáfi R (1988) Demonstration of calciumdependent phospholipase $A_{2}$ activity in membrane preparation of rabbit neutrophils. Absence of activation by fMet-Leu-Phe, phorbol 12-myristate 13-acetate and A-kinase. Biochem J 250: 343-348

27. Robertson RP (1979) Prostaglandins as modulators of pancreatic islet function. Diabetes 28: 943-948

28. Laychock S (1987) Effects of guanosine $3^{\prime}, 5^{\prime}$-monophosphate on glucose utilization in isolated islets of langerhans. Endocrinology 120: $517-524$

29. Laychock $S$ (1987) $\alpha_{2}$-adrenoceptor stimulation affects total glucose utilization in isolated islets of Langerhans. Mol Pharm 32: 241-248

30. Sener A, Blachier F, Malaisse WJ (1988) Crabtree effect in tumural pancreatic islet cells. J Biol Chem 263: 1904-1909

31. Sener A, Rasschaert J, Zähner D, Malaisse WJ (1988) Hexose metabolism in pancreatic islets. Stimulation by D-glucose of [2$\left.{ }^{3} \mathrm{H}\right]$ Glycerol detritiation. Int J Biochem 20: 595-598

32. Conolly TM, Lawing Jr WJ, Majerus PW (1986) Protein kinase C phosphorylates human platelet inositol trisphosphate $5^{\prime}$-phosphomonoesterase, increasing the phosphatase activity. Cell 46: 951-958

33. Rorsman P, Abrahamsson F, Gylfe E, Hellman B (1984) Dual effects of glucose on the cytosolic $\mathrm{Ca}^{2+}$ activity of mouse pancreatic $\beta$-cells. FEBS Lett 170: 196-200

34. Dunlop ME, Larkins RG (1984) Activity of endogenous phospholipase $\mathrm{C}$ and phospholipase $\mathrm{A}_{2}$ in glucose stimulated pancreatic islets. Biochem Biophys Res Commun 120: 820-827

35. Prescott SM, Majerus PW (1983) Characterization of 1,2-diacylglycerol hydrolysis in human platelets. J Biol Chem 258: 764-769

36. De Chaffoy de Courcelles D, Roevens P, van Belle H (1985) R 59022, a diacylgylcerol kinase inhibitor. J Biol Chem 260: $15762-15770$

Received: 30 May 1988

and in revised form: 21 November 1988

Dr. S.E. Hansen

Department of Biochemistry A

The Panum Institute

Blegdamsvej 3

DK-2200 Copenhagen $\mathrm{N}$

Denmark 